\title{
Research on the Competitiveness Promotion Based on Triple Play in Tele- communication Industry
}

\author{
Mengke Yang ${ }^{a, *}$, Mengru Shen ${ }^{\text {,** }}$, Jianqiu Zeng ${ }^{\mathrm{a}}$ and Hao Dong ${ }^{\mathrm{a}}$ \\ ${ }^{a}$ School of Automation, Beijing University of Posts and Telecommunications, Beijing, 10086, China; ${ }^{b}$ School of Traffic \\ and Transportation, Beijing Jiaotong University, Beijing, 100044,China
}

\begin{abstract}
Due to rapidly changing environment based on triple play, the conovation of competitiveness in telecommunication industry has also changed. The operators should adjust their strategic direction timely according to changes in competitive environment. So how to promote the competitiveness under triple play has become a hot issue in telecommunication industry. Based on ISM (Interpretative Structural Model) method, we established the competitiveness promotion model under triple play environment. In this model, the competitiveness structure is divided into explicit layer, driver factor layer and the basic layer; each layer contains several driver factors affecting the telecommunication competitiveness, including technical scalability, market innovation and so on. Through the empirical study on the status of telecommunication industry and the model validation, we proposed strategies to promote the competitiveness for the development of telecommunication industry.
\end{abstract}

Keywords: Competitiveness promotion, ISM, telecommunication industry, triple play.

\section{INTRODUCTION}

Globally, telecommunication industry is a dynamically changing and complex one. Due to rapidly changing environment in which enterprises existing competitive advantage may be lost, enterprises cannot maintain strategic dynamic adaptability [1]. Thus, how to stay competitive in the complex and fickle competitive environment becomes an important proposition of enterprises. Teece and Pisano pointed that enterprises in the dynamic and complex industry need to recognize how change in the competitive environment influent the core competitiveness [2].

Triple-play, also well known as three network convergence, refers to the convergence among telecommunication, Internet and television broadcasting [3]. After the release and implement of triple-play, the competitive environment of Chinese telecommunication industry has changed vigorously. It has become more and more evident that the network convergence will develop towards a higher and broader level. Rapidly changing environment may makes a competitive advantage of enterprises in the past no longer be a competitive advantage. The operators must adjust their strategic direction timely according to changes in competitive environment. So how to promote the competitiveness of telecommunication operators in the new competitive environment has become a hot issue in telecommunication industry.

\section{TRIPLE PLAY IN CHINA}

Triple play is a technological and marketing term for the provisioning, over a single broadband connection, of:

*Address correspondence to these authors at the School of Automation, Beijing University of Posts and Telecommunications, Beijing, 10086, China and School of Traffic and Transportation, Beijing Jiaotong University, Beijing, 100044,China; Tel: 18610680309; E-mail: 15201646681@139.com

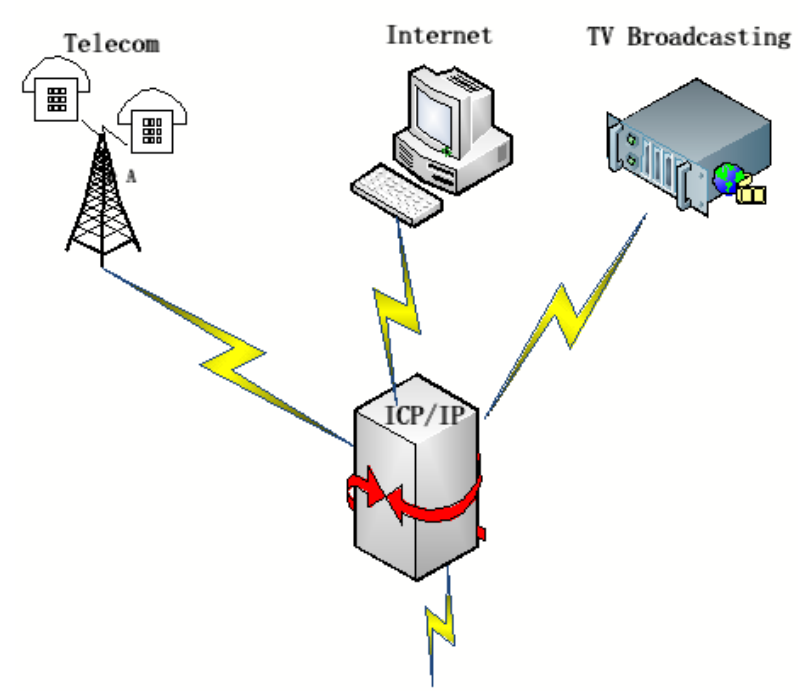

Triple-play

Fig. (1). Triple play.

telecommunication, Internet access and TV broadcasting, as is shown in Fig. (1).

It is generally believed that the network convergence can be divided into three progressive stages: network convergence, service convergence and application convergence.

(1) Network convergence: The network convergence means that users can flexibly switch networks in different places. Network convergence can not only ensure the perceived the quality of the users, but also protect existing investments and save operating and maintenance costs.

(2) Service Convergence: Service convergence means users can choose different services flexibly according to their 
demands without replacing terminals. Service convergence also includes two aspects, which are to use same services on different networks, and to use same services by different types of terminal.

(3) Application convergence: Application convergence includes of telecommunication operators' different kinds of application platforms which makes innovations to their own applications or integrate applications from other industries, SP or CP to attract more attention of users.

Triple play brought about wide-ranging changes. For telecommunication operators, the changes not only indicate to a simple transition or upgrade technology, but to the role conversion on the basis of technological upgrading. According to the requirements and trends of convergence, this paper has come up with the key success factors for telecommunication operators under the triple play environment: converged network, converged services, and close cooperation with the industry chain, application innovation and professional products division.

\section{COMPETITIVENESS MODEL BASED ON TRIPLE PLAY}

\subsection{The Competitiveness in Telecom Industry}

As the previous section mentioned, enterprises of relationship layer, realizing external benefits is the driven force to promote the improvement of enterprises' competitive resources and competitive capabilities; external environment has influence on the changes of competitive resources and competitive capabilities of enterprise at industrial convergence layer, which can also promote the improvement of enterprises' competitiveness. The industrial view of competitiveness just holds that point: industrial environment decides the competitiveness of the enterprises (Fig. 2).

Enterprises' competition capability refers to the capability of conducting its business successfully through adapting to, coordinating and managing internal and external environment. It involves many aspects, such as information capability, technology capability, service capability, and marketing capability and so on. We classify the enterprise competitive capabilities into four categories - strategy and organization layer, technology and network layer, market layer and industrial convergence layer. But how is the actual relationship among them, we need to know further from the enterprise executives and industry experts, correctly classify these four types of competitive capabilities and classify which of those belong to the explicit layer factor, the driver layer factors or basic layer factors.

\subsection{Interpretative Structural Modeling}

ISM, referred as Interpretative Structural Model, is a model which qualitatively shows system elements and the essential interdependence, mutual restrict and sub-factors existed between them. ISM is by relating matrix principle in the graph theory to analyze the overall structure of the complex system, transfer the system structure analysis into topological analysis of isomorphic directed - graph, and then into algebraic analysis, through the operations of incidence matrix to clear the structure characteristics of the system [4].
There are two important matrixes in the ISM method: adjacency matrix and reach ability matrix. The adjacency matrix is used to describe the opposite relationship between each node in the chart. The element Sij of the adjacency matrix $\mathrm{R}$ can be defined as follows:

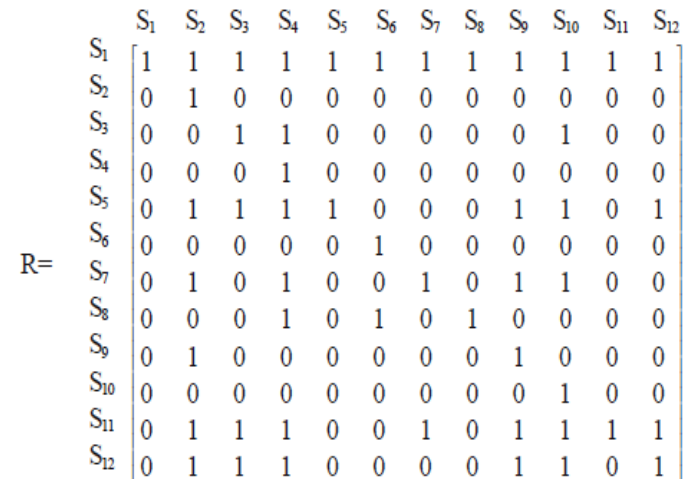

(2) The reachable matrix refers to a matrix form which is to describe the reachable degree between each node in connection diagram, after a certain length pathway.

\begin{tabular}{|c|c|c|c|c|c|c|c|c|c|c|c|c|c|}
\hline & & $\mathrm{S}_{2}$ & $\mathrm{~S}_{4}$ & $\mathrm{~S}_{6}$ & $\mathrm{~S}_{10}$ & $\mathrm{~S}_{9}$ & $\mathrm{~S}_{3}$ & $\mathrm{~S}_{8}$ & $\mathrm{~S}_{7}$ & $\mathrm{~S}_{12}$ & $\mathrm{~S}_{5}$ & $\mathrm{~S}_{11}$ & $\mathrm{~S}_{1}$ \\
\hline & $\mathrm{S}_{2}$ & {$[1$} & 0 & 0 & 0 & 0 & 0 & 0 & 0 & 0 & 0 & 0 & 0 \\
\hline & $\mathrm{S}_{4}$ & 0 & 1 & 0 & 0 & 0 & 0 & 0 & 0 & 0 & 0 & 0 & 0 \\
\hline & $\mathrm{S}_{6}$ & 0 & 0 & 1 & 0 & 0 & 0 & 0 & 0 & 0 & 0 & 0 & 0 \\
\hline & $\mathrm{S}_{10}$ & 0 & 0 & 0 & 1 & 0 & 0 & 0 & 0 & 0 & 0 & 0 & 0 \\
\hline & $\mathrm{S}_{9}$ & 1 & 0 & 0 & 0 & 1 & 0 & 0 & 0 & 0 & 0 & 0 & 0 \\
\hline \multirow[t]{7}{*}{$\mathrm{R}^{*}=$} & $\mathrm{S}_{3}$ & 0 & 1 & 0 & 1 & 0 & 1 & 0 & 0 & 0 & 0 & 0 & 0 \\
\hline & $\mathrm{S}_{8}$ & 0 & 1 & 1 & 0 & 0. & 0. & 1. & 0 & 0 & 0 & 0 & 0 \\
\hline & $\mathrm{S}_{7}$ & 1 & 1 & 0 & 1 & 1 & 0 & 0 & 1 & 0 & 0 & 0 & U \\
\hline & $\mathrm{S}_{12}$ & 1 & 1 & 0 & 1 & 1 & 1 & 0 & 0 & 1 & 0 & 0 & 0 \\
\hline & $\mathrm{S}_{5}$ & 1 & 1 & 0 & 1 & 1 & 1 & 0 & 1 & 1 & & 1 & 0 \\
\hline & $\mathrm{S}_{11}$ & 1 & 1 & 0 & 1 & 1 & 1 & 0 & 1 & 1 & 0 & $\ldots 1$ & $u$ \\
\hline & $\mathrm{S}_{1}$ & 1 & 1 & 1 & 1 & 1 & 1 & 1 & 1 & 1 & 1 & 1 & \\
\hline
\end{tabular}

Reachable matrix $\mathrm{R}$ has an important feature, namely elapse characteristics. According to the passage characteristics, reachable matrix can be obtained by adjacency matrix A plus unit matrix, and then through Boolean matrix calculations.

Make $A_{1}=A+I, A_{2}=(A+I) 2, \ldots . ., \quad A r=(A+I) r$, and then through Boolean algebra operations rules, we can get $A_{1} \neq A_{2} \neq A_{3}$, so reachable matrix $R=A_{2}$.

Matrix $\mathrm{R}$ is called reachable matrix, which showed the degree that each node pass the no longer than (n - 1) access. For the map whose node number is $n$, the length of the longest access does not exceed $(n-1)$. In reachable matrix $R$, if the elements of certain two lines or those of some two columns are same, it indicates that these two lines (two columns) constitute a level [5].

The reason why we chose ISM method mainly is that the adjacency matrix can be used to identify different factors in the relationship between nodes, to reveal the internal structure of competitiveness and rules. By the loop in reachable matrix $\mathrm{R}$, we can analyze enterprise competitive force. Through the calculations, we can find the root of enterprise competitiveness.

\subsection{The Model of Competitiveness Promotion in Telecom Industry}

Under the ISM principle, the telecommunication competitiveness can be divided into the following layers: 


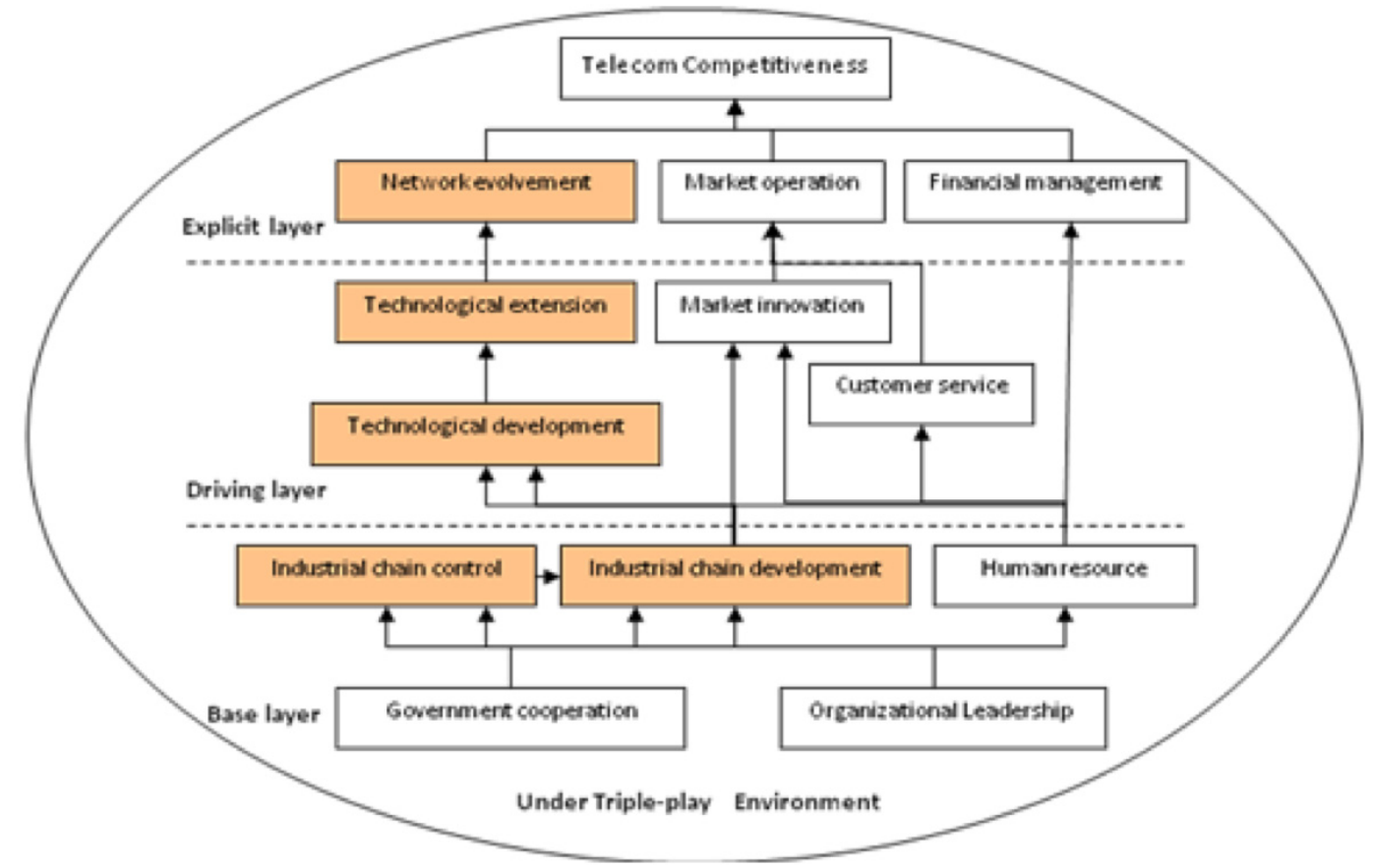

Fig. (2). Competitiveness promotion model under triple-play.

Explicit layer: The improvement of factors of the explicit layer can rapidly promote the enterprises' competitiveness; they are the directly resources and capabilities when the enterprises compete in market.

Driver layer: The factors of the driver layer mainly affect the enterprises' competitiveness through affecting explicit layer factors, support and drive the explicit layer factors. They are the resources and capabilities which maintain competitive advantages in a long-term.

Basic layer: It is the base of the explicit layer and drive layer. Its changes will affect the enterprise's operating direction, competition barriers, and the way of knowledge transformation. It will cause the fundamental impact for the explicit layer and driver layer.

According the questionnaire of experts, explicit layer contains the network edge resources and brand loyalty resources, customer resources and network development capabilities, market operating capacity, financial management capacity. Competitiveness in the driving layer contains technical scalability, technology and development capabilities, marketing and innovation. The base layer contains the control ability in industrial chain, expanding capacity, human capital, government collaboration and the organization leadership [6].

\section{MODEL VALIDATION}

Reliability refers to the credibility of the questionnaire. It mainly represents coherency, consistency, reproducibility and stability of the test result and specifically reflects variation degree of the survey result along with factors such as time and locations. The most common test methods are Cronbach's alpha coefficient. The Cronbach's alpha coefficient which is used in measuring the internal consistency can be calculated as follows: $\ominus$ Calculate the related coefficient matrix of each item to be evaluated and obtain the average value; $\ominus$ Calculate Cronbach's alpha coefficient according to the formula below:

$$
\alpha=\frac{\mathrm{k}}{\mathrm{k}-1}\left(1-\frac{\sum_{\mathrm{i}=1}^{\mathrm{k}} \mathrm{S}_{\mathrm{i}}^{2}}{\mathrm{~S}_{\mathrm{r}}^{2}}\right)
$$

Where: $\mathrm{k}$ stands for total number of the inspecting questions in the questionnaire, $S_{1}^{2}$ stands for variance of the score of I question, and $\mathrm{S}_{\mathrm{r}}^{2}$ stands for variance of total score. It is widely accepted that $0.65-0.70$ is the smallest acceptable value while $0.70-0.80$ is fairly good and $0.80-090$ is extremely good [7].

Validity, also called effectiveness, refers to accuracy degree of the measurement tool in judging the object to be measured. As an important section in empirical study, the validity test can make its result convincible only by satisfying empirical analysis required by validity. The true variance of a set of test scores can be divided into two parts, namely the variance and systematic error variance:

$S_{\mathrm{T}}^{2}=S_{\mathrm{V}}^{2}+S_{\mathrm{I}}^{2}$

And obtained score variance can be represented as

$\mathrm{S}_{\mathrm{x}}^{2}=\mathrm{S}_{\mathrm{V}}^{2}+\mathrm{S}_{\mathrm{I}}^{2}+\mathrm{S}_{\mathrm{E}}^{2}$

Validity is defined as the ratio of the true variance and obtained score variance in a set of test scores:

$r_{X Y}^{2}=\frac{s_{Y}^{2}}{s_{X}^{2}}$

It is generally considered that if the correlation coefficient is over 0.2 , the construct validity is better. And if a variable to a certain factor loading value exceeds 0.5 , we can believe that this variable is associated with this factor significantly. It is generally considered that a factor of variable 
Table 1. The validation results of competitiveness promotion model.

\begin{tabular}{|c|c|c|c|c|}
\hline $\begin{array}{c}\text { Level } \\
\text { Classification }\end{array}$ & $\begin{array}{c}\text { Sub Level } \\
\text { Classification }\end{array}$ & Classification Index Description & Factor Loads & $\begin{array}{c}\text { Accumulated } \\
\text { Contribution Rate } \\
\text { Variance }\end{array}$ \\
\hline \multirow{9}{*}{$\begin{array}{c}\text { Strategic organi- } \\
\text { zational capacity } \\
\text { Cronbach } \alpha=0.82 \\
04\end{array}$} & \multirow{5}{*}{$\begin{array}{l}\text { Organizational } \\
\text { Leadership }\end{array}$} & 1. Prospects of the company's future proactive strategy & 0.709 & \multirow{5}{*}{$45.67 \%$} \\
\hline & & $\begin{array}{l}\text { 2. dynamically adjust business strategy according to changes in the } \\
\text { main body relations of external economic, }\end{array}$ & 0.544 & \\
\hline & & 3. Decision-making capacity of senior leadership & 0.607 & \\
\hline & & 4. Capability to optimize the allocation of corporate resources & 0.453 & \\
\hline & & $\begin{array}{l}\text { 5. Enterprises pass the core values, and create a harmonious culture } \\
\text { through formal and informal channels, }\end{array}$ & 0.578 & \\
\hline & \multirow{2}{*}{$\begin{array}{l}\text { Organizational } \\
\text { Leadership }\end{array}$} & $\begin{array}{l}\text { 6. A two-way transformation capacity of individual knowledge and } \\
\text { organizational knowledge }\end{array}$ & 0.617 & \multirow{2}{*}{$21.46 \%$} \\
\hline & & $\begin{array}{l}\text { 7. Provide staffs with support capability of the platform and imple- } \\
\text { mentation capacity of learning system }\end{array}$ & 0.713 & \\
\hline & \multirow{2}{*}{$\begin{array}{l}\text { Financial manage- } \\
\text { ment Capacity }\end{array}$} & $\begin{array}{l}\text { 8. Enterprises maintain sustainable growth basing completion of the } \\
\text { profitable objectives }\end{array}$ & 0.821 & \multirow{2}{*}{$25.64 \%$} \\
\hline & & 9. Comprehensive operation profitability to invest producing factors & 0.592 & \\
\hline \multirow{11}{*}{$\begin{array}{c}\text { Technology and } \\
\text { network capacity } \\
\text { Cronbach } \alpha=0.72 \\
51\end{array}$} & \multirow{4}{*}{$\begin{array}{c}\text { Technology Devel- } \\
\text { opment's Capabili- } \\
\text { ties }\end{array}$} & 1. Adaptation and adjustment capacity of technology development & 0.415 & \multirow{4}{*}{$25.66 \%$} \\
\hline & & 2. Ability to absorb new technologies & 0.471 & \\
\hline & & 3. Capacity of information's analysis and processing & 0.422 & \\
\hline & & 4. Development capabilities of new product / business & 0.507 & \\
\hline & \multirow{2}{*}{$\begin{array}{l}\text { Technology Scal- } \\
\text { ability’s Capabilities }\end{array}$} & 5. The core technology extension areas & 0.562 & \multirow{2}{*}{$11.31 \%$} \\
\hline & & 6. Development prospects of core technology & 0.812 & \\
\hline & \multirow{5}{*}{$\begin{array}{l}\text { Capacity of the } \\
\text { Network Develop- } \\
\text { ment }\end{array}$} & 7. Networks' capability to match future business development & 0.554 & \multirow{5}{*}{$60.91 \%$} \\
\hline & & 8. Business monitoring capability & 0.491 & \\
\hline & & 9. Networks' optimization capabilities & 0.798 & \\
\hline & & 10. The laying capacity of the last mile & 0.737 & \\
\hline & & 11. Capacity of smooth upgrading to higher networks & 0.804 & \\
\hline \multirow{8}{*}{$\begin{array}{c}\text { Marketing } \\
\text { capabilities } \\
\text { Cronbach } \alpha=0.82 \\
21\end{array}$} & \multirow{3}{*}{ Market Innovation } & 1 Guide customers to need new products and technologies & 0.623 & \multirow{3}{*}{$34.68 \%$} \\
\hline & & 2. Marketers' marketing development capabilities & 0.587 & \\
\hline & & $\begin{array}{l}\text { 3. Quickly adjust the marketing strategy according to market de- } \\
\text { mand }\end{array}$ & 0.539 & \\
\hline & \multirow{2}{*}{ Market Capacity } & 4. Capability of the integrated use in marketing mix & 0.534 & \multirow{2}{*}{$31.26 \%$} \\
\hline & & 5. New products quickly to market & 0.615 & \\
\hline & \multirow{3}{*}{ Customer Service } & 6. Satisfaction of customers & 0.511 & \multirow{3}{*}{$33.25 \%$} \\
\hline & & 7. The effect of handling complaints & 0.623 & \\
\hline & & $\begin{array}{l}\text { 8. The business flow balance of electronic channels and physical } \\
\text { channels }\end{array}$ & 0.582 & \\
\hline
\end{tabular}


Table 1. Contd......

\begin{tabular}{|c|c|c|c|c|}
\hline $\begin{array}{c}\text { Level } \\
\text { Classification }\end{array}$ & $\begin{array}{c}\text { Sub Level } \\
\text { Classification }\end{array}$ & Classification Index Description & Factor Loads & $\begin{array}{c}\text { Accumulated } \\
\text { Contribution Rate } \\
\text { Variance }\end{array}$ \\
\hline \multirow{8}{*}{$\begin{array}{c}\text { Industrial inte- } \\
\text { gration capabili- } \\
\text { ties } \\
\text { Cronbach } \alpha=0.77 \\
42\end{array}$} & \multirow{2}{*}{$\begin{array}{l}\text { Government Col- } \\
\text { laboration }\end{array}$} & 1. Actively ask for support from governments at all levels & 0.572 & \multirow{2}{*}{$24.33 \%$} \\
\hline & & 2. Using policy capacity of governments at all levels & 0.523 & \\
\hline & \multirow{4}{*}{$\begin{array}{c}\text { The Expand Capac- } \\
\text { ity of Industrial } \\
\text { Chain }\end{array}$} & $\begin{array}{l}\text { 3. Develop the market, the formation of complementary coordina- } \\
\text { tion with suppliers of complementary persons / partners }\end{array}$ & 0.447 & \multirow{4}{*}{$35.61 \%$} \\
\hline & & $\begin{array}{l}\text { 4. The capacity of coordination with competitors / substitutes on } \\
\text { easing competition }\end{array}$ & 0.453 & \\
\hline & & $\begin{array}{l}\text { 5. Interactive learning with customers, using innovation and cus- } \\
\text { tomer participation }\end{array}$ & 0.465 & \\
\hline & & $\begin{array}{l}\text { 6. Make technical cooperation and innovation with suppliers / com- } \\
\text { plementary persons / partners }\end{array}$ & 0.667 & \\
\hline & \multirow[t]{2}{*}{ Chain Control } & $\begin{array}{l}\text { 7. Prevent the supplier / complementary persons / partners from } \\
\text { becoming competitors }\end{array}$ & 0.432 & \multirow[t]{2}{*}{$41.94 \%$} \\
\hline & & 8. Use competitor / substitute to make it a partner & 0.488 & \\
\hline
\end{tabular}

loads is greater than 0.4 , the variable can reasonably be classed into the factor. SPSS 17.0 software was used to evaluate the reliability and effectiveness of the model and further verify the model $[8,9]$. The results shows that the indexes are significantly correlated and the model is valid for the practice., as is shown in Table $\mathbf{1}$.

\section{THE PROMOTION STRATEGY OF TELECOM- MUNICATION COMPETITIVENESS IN CHINA}

Based on the model of telecommunication competitiveness above, telecommunication operators should enhance the adaptability of technologies, carefully arrange network constructions, the adaptability of networks for future business development, and reserve room for smooth upgrading to advanced networks. To achieve these goals, telecommunication operators need to improve their capabilities to expand and control the industrial chains. Specifically, they should cooperate with equipment manufacturers, software developers, content providers of value added service, server providers, and terminal manufacturers to jointly carry out technological cooperation and innovation. Telecommunication operators also need to ally themselves with those enterprises on market development while preventing those enterprises from becoming their competitors. That's to say telecommunication operators in triple play age should not only develop markets through terminal manufacturers and social sales channels, but also cooperate with radio and television companies to jointly develop markets to promote the business innovation in China [10].

\section{CONFLICT OF INTEREST}

The authors confirm that this article content has no conflict of interest.

\section{ACKNOWLEDGEMENTS}

This work is supported by National Science Technology Support Project (NO.2011BAH16B07), China and Yunnan province universities Social Science Cooperation Projects (NO. SYSX201206), China.

\section{REFERENCES}

[1] L. Barton, "Strategic Factor Markets: Expectations, Luck, and Business Strategies," Management Science, vol. 32, pp. 285-291, 1986

[2] D. J. Teece, G. Pisano, and A. Shuen, "Dynamic Capabilities and Strategic Management “, Strategic Management Journal, vol. 18, pp. 509-503, 1997.

[3] P. Pereira, T. Ribeiro, and J. Vareda, "Delineating markets for bundles with consumer level data: The case of triple-play", International Journal of Industrial Organization, vol. 31, pp . 760$773,2013$.

[4] M. Xu, "Analysis of Competitive Power of Regional Telecommunication Enterprises Based on ISM," Value Engineering, vol. 10, pp. 23-35, 2005.

[5] V.R. Pramod, and D.K. . Banwet, "Fuzzy ISM for analyzing the inhibitors of a telecommunication service supply chain", International Journal of Information Systems and Supply Chain Management, vol. 6, pp. 77-98, 2013.

[6] L. Hou," "A review of telecommunication markets in the EU: What did the European Commission learn or not from the past?", Computer Law and Security Review, vol. 30, pp. 710-719, 2014.

[7] O. Schilke, and B. W. Wirtz, "Consumer acceptance of service bundles: An empirical investigation in the context of broadband triple play", Information and Management, vol. 49, pp. 81-88, 2012.

[8] K. Matzler, and E. Sauerwein, "The factor structure of customer satisfaction: An empirical test of the importance grid and the penalty-reward-contrast analysis," International Journal of Service Industry Management, vol. 13, pp. 314-332, 2012.

[9] H. Zhang, and Y. Ding, "Research on the relationship of institutional innovation, organizational learning and synergistic effect: An empirical study of Chinese university spin-offs," Journal of Industrial Engineering and Management, vol. 7, pp. 645-659, 2014. 
[10] M. Bourreau, P. Lupi, and F. M. Manenti, "Old technology upgrades, innovation, and competition in vertically differentiated

markets", Information Economics and Policy, vol. 29, pp. 10-31, 2002 .

Received: June 10,2015

Revised: July 29, 2015

Accepted: August 15,2015

(C) Yang et al.; Licensee Bentham Open.

This is an open access article licensed under the terms of the (https://creativecommons.org/licenses/by/4.0/legalcode), which permits unrestricted, noncommercial use, distribution and reproduction in any medium, provided the work is properly cited. 